\title{
Characterization of Capsicum species using anatomical and molecular data
}

\author{
G.B. Dias' ${ }^{1}$, V.M. Gomes ${ }^{2}$, T.M.S. Moraes ${ }^{1}$, U.P. Zottich ${ }^{2}$, G.R. Rabelo ${ }^{1}$, \\ A.O. Carvalho ${ }^{2}$, M. Moulin ${ }^{3}$, L.S.A. Gonçalves ${ }^{3}$, R. Rodrigues ${ }^{3}$ and \\ M. Da Cunha ${ }^{1}$
}

${ }^{1}$ Setor de Biologia Vegetal, Laboratório de Biologia Celular e Tecidual, Centro de Biociências e Biotecnologia,

Universidade Estadual do Norte Fluminense, Rio de Janeiro, RJ, Brasil

${ }^{2}$ Laboratório de Fisiologia e Bioquímica de Microrganismos,

Universidade Estadual do Norte Fluminense, Rio de Janeiro, RJ, Brasil

${ }^{3}$ Laboratório de Melhoramento Genético Vegetal,

Universidade Estadual do Norte Fluminense, Rio de Janeiro, RJ, Brasil

Corresponding author: M. Da Cunha

E-mail: maurauenf@gmail.com

Genet. Mol. Res. 12 (4): 6488-6501 (2013)

Received August 7, 2012

Accepted November 22, 2012

Published February 28, 2012

DOI http://dx.doi.org/10.4238/2013.February.28.29

ABSTRACT. Capsicum species are frequently described in terms of genetic divergence, considering morphological, agronomic, and molecular databases. However, descriptions of genetic differences based on anatomical characters are rare. We examined the anatomy and the micromorphology of vegetative and reproductive organs of several Capsicum species. Four Capsicum accessions representing the species C. annuum var. annuum, C. baccatum var. pendulum, C. chinense, and $C$. frutescens were cultivated in a greenhouse; leaves, fruits and seeds were sampled and their organ structure analyzed by light and scanning electronic microscopy. Molecular accession characterization was made using ISSR markers. Polymorphism was observed among tector trichomes and also in fruit color and shape. High variability among accessions was detected by ISSR markers. Although the species studied 
present a wide morphological and molecular variability, this variability was not reflected in anatomical features.

Key words: Genetic diversity; Sweet and chili pepper; ISSR markers; Micromorphology; Anatomy

\section{INTRODUCTION}

The Capsicum species are members of the Solanaceae family (tribe Solaneae, subtribe Capsicinae), which includes tomato, potato, tobacco, and petunia. This genus contains about 31 species (Moscone et al., 2007) of which five are domesticated, namely $C$. annuиm L., $C$. frutescens L., C. chinense Jacq., C. baccatum L., and C. pubescens R. (IBPGR, 1983). The production of sweet and chili pepper crops is an important agribusiness worldwide, where this market stimulates family farming and increased employment and income generation from agriculture (Reifschneider and Ribeiro, 2008).

The main producing region in the world is Asia, especially represented by China which produced approximately 254 thousand tons of hot and sweet peppers in 2008, followed by India producing 1.23 million tons (FAOSTAT, 2010). Reifschneider and Ribeiro (2008) argue that in Brazil this is a market that moves around 100 M USD per year, including domestic consumption and exports. Also according to these authors, red peppers account for third place in production and consumption of seasoning vegetables in Brazil. Therefore, this market stimulates agriculture in Brazil (Vilela et al., 2008).

Capsicum is native to Central and South America (Perry et al., 2007), where this genus is believed to have been selected in two areas of origin, one called the primary center and then introduced to other regions called secondary centers (Mongkolporn and Taylor, 2011). Brazil is considered a secondary center of diversity of this genus.

Due to the selection process, varieties with new morphological characters arose in these new areas (Clement et al., 2010), and their genetic variability is poorly understood. Many varieties have overlapping morphological character states, potentially leading to unresolved or erroneous species identification. The great importance of correct species identification can be exemplified by the knowledge of the anatomical and morphological characteristics that are necessary for studies on the interactions between plants and herbivores and other natural enemies (Price, 1997). Additionally, a correct botanical species classification is essential for the proper management of germplasm collections. An erroneous identification of species maintained in gene banks can lead to losses ranging from the propagation and inadequate conservation of accessions to the delivery of misidentified genetic material to other institutions, resulting in a waste of time and financial resources (Sudré et al., 2010).

The genus Capsicum has a very complex taxonomy, and its circumscription into one species or another can vary considerably based on the characteristics of the leaves, flowers and fruits, and these variations are often factors related to the geographic and weather conditions where the plants grow (Petters, 2002). In general, the identification of this genus and species is carried out by morphological features observed mainly in flowers (Sudré et al., 2010). However, flower characteristics are not enough and, in general, a combination of diagnostic characters associated with genetic characteristics is usually required to identify and differentiate Capsicum species. 
The characterization and evaluation of domesticated Capsicum species are particularly interesting for gene bank curators, since a wide variability, not yet fully known and exploited, is available for these species (Ince et al., 2009). Despite the accuracy in estimating genetic divergence among accessions by molecular markers, knowledge of the phenotype given by morphological and molecular descriptors is still important. Besides the aspect of correct species identification, the characterization and evaluation of conserved genotypes are of fundamental importance for improving our knowledge and making it possible to detect better genotypes for use in breeding programs and duplicates (Laurentin, 2009).

Thus, this study aimed to evaluate the anatomy and micromorphology of vegetative and reproductive organs of 4 species of Capsicum, and to detect their special chemical constituents, providing data to assist in the understanding of these species, for ecological and medicinal studies. In addition, we determined the genetic divergence between the four accessions of Capsicum spp based on morphological and molecular data and estimated the relation between genetic distances obtained based on morphological characteristics by inter simple sequence repeat (ISSR) markers.

\section{MATERIAL AND METHODS}

\section{Plant materials}

Four accessions from the Capsicum gene bank of Centro de Ciências e Tecnologias Agropecuárias of the Universidade Estadual do Norte Fluminense were studied. Seeds of each accession were sown in a polystyrene seed tray with 128 cells filled with organic substrate and grown until seedling stage. Seedlings were individually transferred to 5-L plastic pots filled with a mixture of organic substrate:sand $(3: 1, \mathrm{w} / \mathrm{w})$. Plants were kept in a greenhouse, fertilized only once and exposed to daylight illumination during the experimental period. Completely expanded leaves, ripe fruits and seeds of the species C. annuum (accession No. UENF1381), C. baccatum (accession No. UENF1732), C. chinense (accession No. UENF1755), and C. frutescens (accession No. UENF1775) were sampled and used for anatomical characterization. These materials were fixed immediately after collection and processed as described in the following sections. These accessions showed remarkable phenotypic differences in growth form, corolla shape and color, fruit shape and color and seed color (Table 1) (Moscone et al., 2007). For the genetic divergence study, seeds were sown and seedlings were individually transferred to 0.5 -L plastic pots and kept as described before for a period of 3 weeks. Young leaves of 5 plants of each species were collected, frozen in liquid nitrogen and stored at $-70^{\circ} \mathrm{C}$ until used.

\begin{tabular}{|c|c|c|c|c|}
\hline Capsicum sp & Growth form & Corolla shape and color & Fruit shape and color & Seed color \\
\hline C. chinense & Herb or sushrub $(0.5-2 \mathrm{~m})$ & Stellate white or cream & $\begin{array}{l}\text { Sherical or conical; red, orange, } \\
\text { yellow, white or brown }\end{array}$ & Yellowish \\
\hline C. annuum & Herb or sushrub $(1-2 \mathrm{~m})$ & Stellate white or cream (expectionally violet) & Highly variable shape, red & Yellowish \\
\hline C. baccatum & Shurb $(0.6-2 \mathrm{~m})$ & Stellate white with greenish spots in the throat & Ovoid or fusiform red & Yellowish \\
\hline C. frutescens & Herb or sushrub $(1-2 \mathrm{~m})$ & Stellate white or cream & Elongate red & Yellowish \\
\hline
\end{tabular}

Adapted from Moscone et al., 2007. 


\section{Light microscopy}

Samples from each plant organ were immediately fixed for $2 \mathrm{~h}$ in a solution of $2.5 \%$ glutaraldehyde and $4.0 \%$ formaldehyde in a $0.05 \mathrm{M}$ sodium cacodylate buffer at $\mathrm{pH} 7.2$ (Klein et al., 2004). Afterwards, the samples were washed three times with buffer for $30 \mathrm{~min}$ and then fixed for $2 \mathrm{~h}$ at room temperature with $1.0 \%$ osmium tetroxide in the same buffer. The fixed samples were dehydrated using an acetone series and then embedded in epoxy resin $\left(\right.$ Epon $\left.^{\circledR}\right)$. Thin sections $(4.0 \mu \mathrm{M})$ were then made and stained with $0.05 \%$ toluidine blue (O'Brien et al., 1964). The glass slides were sealed with Entellan ${ }^{\circledR}$ (Merck), and the material was examined with an Axioplan microscope (ZEISS). Images were obtained with a Canon PowerShot A640 camera and the Axiovision software (ZEISS).

\section{Scanning electron microscopy}

Samples were fixed, post-fixed and dehydrated, as done for the light microscopy study. The samples were then critical point dried with $\mathrm{CO}_{2}$, sputter coated with $20 \mathrm{~nm}$ gold, and observed using a ZEISS DSEM 962 scanning electron microscope.

\section{Molecular analysis}

The ISSR marker was used for molecular characterization. Besides the four Capsicum accessions, a tomato (Solanum lycopersicon) cultivar (Rio Grande) was used as an outgroup control. Three hundred milligrams of macerated leaf of each sample were transferred to $1.5-\mathrm{mL}$ tubes and immersed in liquid nitrogen for extraction of DNA according to the protocol by Doyle and Doyle (1990) with modifications as described in the following. The sample was mixed with $1 \mathrm{~mL}$ preheated extraction buffer containing 2\% CTAB, $1.4 \mathrm{mM} \mathrm{NaCl}, 20 \mathrm{mM}$ EDTA, $100 \mathrm{mM}$ Tris- $\mathrm{HCl}, \mathrm{pH} 8.0,1 \% \mathrm{PVP}$, and $0.2 \% \beta$-mercaptoethanol, along with $5 \mu \mathrm{L} 10 \mathrm{mg} / \mathrm{mL}$ proteinase $\mathrm{K}$. These samples were incubated at $37^{\circ} \mathrm{C}$ for $30 \mathrm{~min}$ with gentle stirring every $10 \mathrm{~min}$ and subsequently incubated at $65^{\circ} \mathrm{C}$ for $30 \mathrm{~min}$. The samples were then centrifuged at $8000 \mathrm{~g}$ for $10 \mathrm{~min}$, and the supernatant (about $800 \mu \mathrm{L}$ ) was transferred to a new tube, to which was added an equal volume of phenol:chloroform:isoamyl alcohol (25:24:1). The phases were mixed by gentle inversion for approximately 10 min until becoming cloudy. The supernatant (aqueous phase) was separated by centrifugation at $8000 \mathrm{~g}$ for $10 \mathrm{~min}$ and transferred to a new tube, to which $200 \mathrm{~mL} 2.0 \mathrm{M} \mathrm{NaCl}$ containing 4\% PEG (final concentration) were added for complete removal of proteins and DNA recovery. The samples were then incubated for $15 \mathrm{~min}$ at $4{ }^{\circ} \mathrm{C}$ and centrifuged again at $8000 \mathrm{~g}$ for $10 \mathrm{~min}$. Nucleic acids were precipitated by adding twothirds volume $(400 \mu \mathrm{L})$ cold isopropanol and incubating for $20 \mathrm{~min}$ at $-70^{\circ} \mathrm{C}$. The precipitates were pelleted by centrifugation at $8000 \mathrm{~g}$ for $10 \mathrm{~min}$. The supernatants were discarded and the precipitates washed twice with $200 \mu \mathrm{L} \mathrm{75 \%}$ ethanol with ammonium acetate, to remove salt (between each wash, the tubes were centrifuged at $8000 \mathrm{~g}$ for $5 \mathrm{~min}$ ). After discarding the last supernatants, the samples were dried at room temperature, until ethanol was removed. The samples were resuspended in $100 \mu \mathrm{L}$ TE solution (10 mM Tris-HCl, $1 \mathrm{mM}$ EDTA, $\mathrm{pH}$ 8.0) with RNase A at a final concentration of $10 \mathrm{mg} / \mathrm{mL}$ and incubated in a water bath at $37^{\circ} \mathrm{C}$ for $30 \mathrm{~min}$ and then the samples was stored at $-20^{\circ} \mathrm{C}$ until use. DNA concentration was determined NanoDrop spectrophotometer (Thermo Scientific) and adjusted to $1 \mu \mathrm{g} / \mu \mathrm{L}$.

PCR was performed according to the protocol by Williams et al. (1990) with some 
modifications. The final reaction volume was $13 \mu \mathrm{L}$ containing the following: $10 \mathrm{mM}$ Tris$\mathrm{HCl}, \mathrm{pH} 8.3,50 \mathrm{mM} \mathrm{KCl}, 2.4 \mathrm{mM} \mathrm{MgCl}, 100 \mu \mathrm{M}$ of each deoxyribonucleotide (dATP, dCTP, dGTP, and dTTP), $0.4 \mu \mathrm{M}$ oligonucleotide primers, $10 \mathrm{ng}$ genomic DNA, and $0.75 \mathrm{U}$ Taq DNA polymerase. First, $2 \mu \mathrm{L}$ DNA were placed in the tube, followed by $11 \mu \mathrm{L}$ previously described mix. PCR (StepOne Plus Thermal Cycler - Applied Biosystems) was as follows: 3 min at $94^{\circ} \mathrm{C}$ for the initial denaturation; 40 cycles consisting of $94^{\circ} \mathrm{C}$ for $1 \mathrm{~min}, 40-50^{\circ} \mathrm{C}$ for $1 \mathrm{~min}$ (depending on the primer), and $72^{\circ} \mathrm{C}$ for $3 \mathrm{~min}$; and a final extension step of $72^{\circ} \mathrm{C}$ for 7 min. The amplified fragments were separated on a $1.5 \%$ agarose gel, stained with GelRed, and visualized under UV light (photodocumented with Minibis Pro, Bio-imaging System).

The amplification conditions were optimized for each primer to determine the best temperature for amplification. We used 41 primers (Kumar et al., 2011; Refaat et al., 2007; Patel et al., 2011) as described in Table 2 (Primers, Columbia, Canada).

Table 2. ISSR primers used, optimal annealing temperatures, and number of polymorphic and monomorphic bands generated in the study of 4 accessions of Capsicum and 1 accession of Solanum lycopersum.

\begin{tabular}{|c|c|c|c|c|c|}
\hline No. & Sequence (5'-3') & $\mathrm{Ta}\left({ }^{\circ} \mathrm{C}\right)$ & Polymorphic bands & Monomorphic bands & Total of bands \\
\hline 1 & $(\mathrm{AC})_{8} \mathrm{CT}$ & 47 & 9 & 2 & 11 \\
\hline 2 & $(\mathrm{GA})_{8}^{8} \mathrm{YT}$ & 47 & 9 & 1 & 10 \\
\hline 3 & $(\mathrm{GT})_{8}^{8} \mathrm{YC}$ & 47 & 11 & 1 & 12 \\
\hline 4 & $(\mathrm{AC})_{8}^{8} \mathrm{YA}$ & 47 & 13 & 0 & 13 \\
\hline 5 & $(\mathrm{GT})_{8}^{8} \mathrm{YG}$ & 47 & 11 & 0 & 11 \\
\hline 6 & $(\mathrm{AC})_{8}^{8} \mathrm{YT}$ & 47 & 10 & 2 & 12 \\
\hline 7 & $\mathrm{GAC}(\mathrm{CAA})_{5}$ & 47 & 6 & 0 & 6 \\
\hline 8 & $\mathrm{CTC}(\mathrm{GT})_{8}$ & 47 & 14 & 0 & 14 \\
\hline 9 & (GAA) EAA & 49.5 & 14 & 0 & 14 \\
\hline 10 & (AG) $\mathrm{TG}$ & 47 & 10 & 0 & 10 \\
\hline 11 & $(\mathrm{CCA})_{7}$ & 47 & 9 & 1 & 10 \\
\hline 12 & $(\mathrm{GCC})_{5}^{7}$ & 47 & 4 & 0 & 4 \\
\hline 13 & $\mathrm{CGA}_{7}$ & 50 & 14 & 0 & 14 \\
\hline 14 & $\mathrm{~T}(\mathrm{TTA})_{4} \mathrm{TT}$ & 46 & 14 & 1 & 15 \\
\hline 15 & $(\mathrm{GTG})_{4} \mathrm{RC}$ & 49.5 & 14 & 0 & 14 \\
\hline 16 & $\mathrm{CG}(\mathrm{A})_{7}$ & 50 & 24 & 1 & 25 \\
\hline 17 & $(\mathrm{GC}), \mathrm{CGCCGCCGCC}$ & 50 & 17 & 3 & 20 \\
\hline 18 & $(\mathrm{GT})_{8} \mathrm{CTC}$ & 50 & 0 & 6 & 6 \\
\hline 19 & $\mathrm{TACA}(\mathrm{GCA})_{3} \mathrm{G}$ & 50 & 19 & 0 & 19 \\
\hline 20 & $\mathrm{CT}_{8} \mathrm{AC}$ & 50 & 20 & 0 & 20 \\
\hline 21 & $\mathrm{CT}_{8}^{8} \mathrm{GC}$ & 50 & 27 & 0 & 27 \\
\hline 22 & $(\mathrm{CA})_{6}^{8} \mathrm{AG}$ & 50 & 13 & 0 & 13 \\
\hline 23 & $(\mathrm{GT}){ }_{6}^{\circ} \mathrm{GG}$ & 50 & 13 & 20 & 0 \\
\hline 24 & CGAA(TTA) ${ }_{3}$ TT & 50 & 10 & 0 & 10 \\
\hline 25 & $(\mathrm{AA})_{2}(\mathrm{TAA})_{3}^{3} \mathrm{~T}$ & 44 & 5 & 1 & 6 \\
\hline 26 & $(\mathrm{AA})_{2} \mathrm{AT}(\mathrm{AAT})_{3}$ & 48 & 13 & 2 & 15 \\
\hline 27 & $\mathrm{TG}_{8}$ & 50 & $*$ & $*$ & $*$ \\
\hline 28 & $\mathrm{TG}_{7} \mathrm{~T}$ & 50 & $*$ & $*$ & $*$ \\
\hline 29 & $\mathrm{TG}_{9} \mathrm{~T}$ & 50 & $*$ & $*$ & $*$ \\
\hline 30 & $\mathrm{CT}(\mathrm{ATT})_{4}$ & 41 & $*$ & $*$ & $*$ \\
\hline 31 & TCA(TTA) $)_{3}$ TT & 50 & $*$ & $*$ & $*$ \\
\hline 32 & $(\mathrm{CT})_{8} \mathrm{AGG}$ & 50 & $*$ & $*$ & $*$ \\
\hline 33 & $\mathrm{GA}_{8} \mathrm{~T}$ & 50 & $*$ & $*$ & $*$ \\
\hline 34 & $\left(\mathrm{GGGTG}_{3}\right.$ & 50 & $*$ & $*$ & $*$ \\
\hline 35 & $\mathrm{CT}_{8} \mathrm{TG}^{3}$ & 50 & $*$ & $*$ & $*$ \\
\hline 36 & $(\mathrm{CA})_{6}^{8} \mathrm{AC}$ & 50 & $*$ & $*$ & $*$ \\
\hline 37 & $(\mathrm{GT})_{6} \mathrm{CC}$ & 50 & $*$ & $*$ & $*$ \\
\hline 38 & $\mathrm{CA}(\mathrm{CCA})_{2} \mathrm{CGC}$ & 50 & $*$ & $*$ & $*$ \\
\hline 39 & $\mathrm{GA}(\mathrm{GGA}){ }_{2} \mathrm{GGC}$ & 50 & $*$ & $*$ & $*$ \\
\hline 40 & $\mathrm{GA}(\mathrm{ATT})$ & 50 & $*$ & $*$ & $*$ \\
\hline \multirow[t]{2}{*}{41} & $(\mathrm{AG})_{8} \mathrm{CG}^{4}$ & 50 & $*$ & $*$ & $*$ \\
\hline & Total of bands/column & & 323 & 41 & 331 \\
\hline
\end{tabular}

$\mathrm{Ta}=$ annealing temperature. 
The statistical analysis of the data was performed considering a binary matrix that was constructed using the value ' 1 ' to indicate band present and ' 0 ' to indicate band absent. The monomorphic bands were eliminated. The binary data were submitted to analysis using the GENES program (Cruz, 2006), and a dendrogram was constructed using the R program (R Development Core Team, 2009). Clustering was performed using unweighted paired group method with arithmetic averages, and the results were validated by calculating the cophenetic correlation coefficient.

\section{RESULTS AND DISCUSSION}

\section{Leaf anatomy}

The leaf epidermis of the four species studied displayed a uniseriate epidermis covered by a slightly thicker cuticle on the adaxial surface. The epidermal cells had a rectangular shape, and the adaxial surface cells were larger than the abaxial cells (Figure 1A). The external periclinal cell walls of the adaxial epidermal cells of $C$. baccatum and $C$. frutescens were slightly convex. The shape of the external periclinal cell walls of the adaxial epidermal cells of both these species appeared to be related to the radiation intensity and the ability of plants to capture sunlight, because these plants are found in the forest. Epidermal cells with convex periclinal walls may be advantageous in shaded environments, because they capture light more efficiently (Smith et al., 1997). Convex periclinal walls of the epidermal cells have been observed in other species of Psychotria that grow in the understorey (Moraes et al., 2011).

On the adaxial surface of the species, the epidermal cells showed sinuous anticlinal walls (Figure 1B). The sinuous outline of the anticlinal walls has been previously described in other genera of Solanaceae, such as Physalis and Nicandra, and in other sections of the subgenus Solanum and Geminata, such as $S$. dulcamara L., S. nigrum L., S. seaforthianum Andrews, S. swartzianum Roem. \& Schult., S. tuberosum L., and S. pseudocapsicum L. Cosa et al. (2002) reported that the outline of the anticlinal epidermal walls shows varying degrees of sinuosity according to the species and the surface observed. For example, in S. palinacanthum, S. elaeagnifolium and $S$. juvenal, this outline is slightly sinuous, whilst in S. sisymbriifolium it is strongly sinuous, for both leaf surfaces.

The presence of anomocytic stomata on both surfaces of the four species studied classified the leaves as amphistomatic (Figure 1B and C). According to Metcalfe and Chalk (1950), amphistomatic leaves are common in Solanaceae, but Cosa et al. (2002) described hypostomatic leaves in some species of this family.

Polymorphism was observed for trichomes. The species $C$. chinense and C. baccatum showed tector trichomes, and in C. baccatum the trichomes were hooked. Glandular trichomes were observed in C. annuum, C. frutescens and C. baccatum (Figure 1D and E). According to Metcalfe and Chalk (1983), in some cases, trichomes may serve to characterize some families. The development of trichomes from the epidermis usually results from differential enlargement and subsequent divisions of the epidermal cells (Carlquist, 1958). The presence of glandular trichomes is a characteristic of the species of the genus Solanum and many other Solanaceae as well, with the known exception of Nicotiana glauca and Solandra nitida (Maiti et al., 2002). Glandular trichomes are characterized by having specialized cells that contain or exude, on contact with pests, sticky and/or toxic exudates that may entrap, irritate or potentially kill some pests (Simmons et al., 2003). 

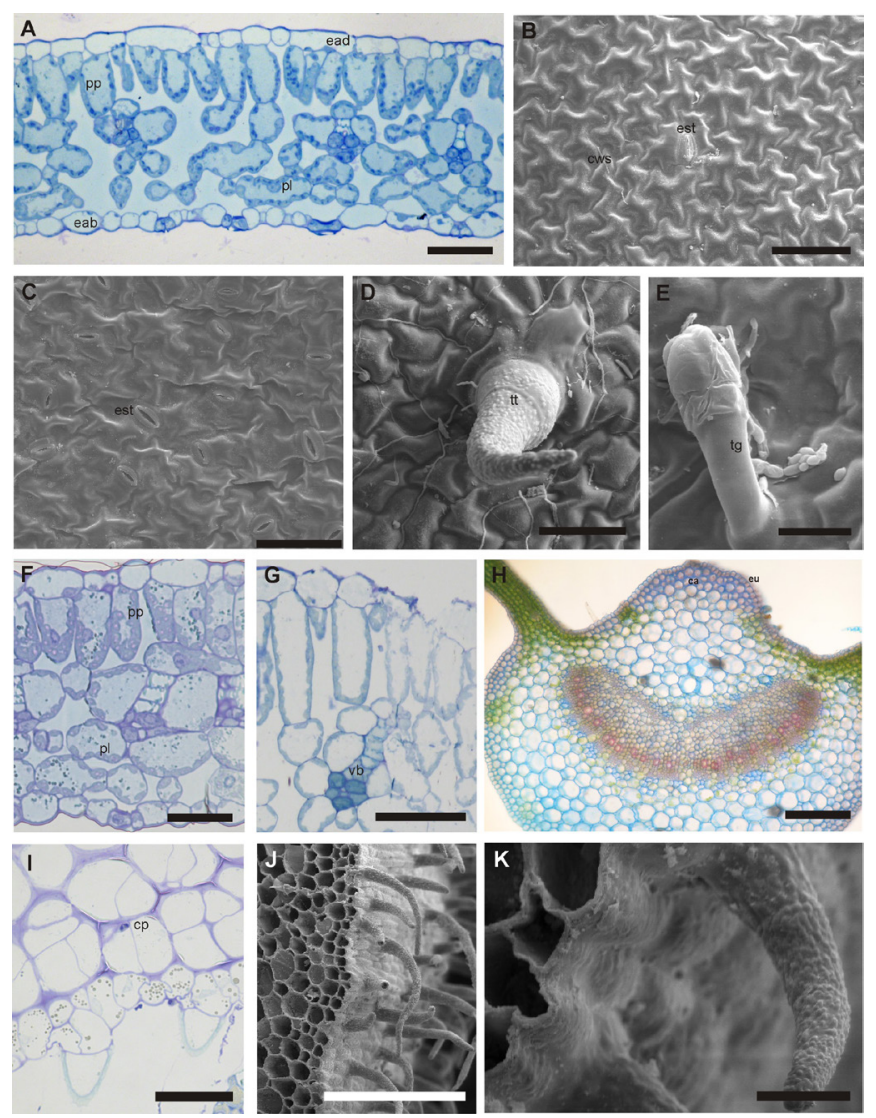

Figure 1. A. Cross-section of leaf from Capsicum chinense. B. Abaxial surface of the C. baccatum with ornamentation and fine cuticular wax layer epiticular. C. Cuticular ornamentation on the abaxial surface of $C$. annum. Anomocytic stomata on both leaf surfaces. D. Tector trichome-ornamented surfaces of the leaf the $C$. chinense. E. Cuticular ornamentation on the adaxial surface of the $C$. frutescens. Glandular trichome-ornamented surfaces of the leaf. F. Detail of the leaf blade. G. Detail of the vascular system the C. baccatum. H. Anatomical cut petiole the C. chinense. I. Tector trichome-ornamented surfaces of the petiole. J. Cross-section of petiole, the scanning electron microscope showing tector trichomes. K. Detail the tector trichomes ornamented. Bars: A and $\mathrm{H}=50 \mu \mathrm{M} ; \mathrm{B}$ and $\mathrm{C}=25 \mu \mathrm{M} ; \mathrm{D}$ to $\mathrm{G}, \mathrm{I}$, and $\mathrm{K}=20 \mu \mathrm{M} ; \mathrm{J}=200 \mu \mathrm{M}$. pp = palisade parenchyma; ead = adaxial epidermis; $\mathrm{pl}=$ spongy parenchyma; $\mathrm{eab}=$ abaxial epidermis; $\mathrm{est}=$ stomata; $\mathrm{cws}=$ sinuous cell wall; $\mathrm{tt}=$ tector trichome; $\mathrm{tg}=$ glandular trichome.

In several plant species where the composition of the secretion has been characterized, this secretion is composed of different substances belonging to diverse chemical classes. Moreover, the secretion has been related to plant defense against pathogens and pests as indicated by biological activity across different organisms (Amme et al., 2005).

No polymorphism was detected for leaf blade. The four Capsicum species studied showed a dorsiventral mesophyll leaf blade (Figure 1F), which has been described by several authors for Solanaceae family (Cosa et al., 2002; Granada-Chacón et al., 2004). Dorsiventral mesophyll is the most frequent in the Solanaceae (Cosa et al., 2002; Granada-Chacón et al., 2004). The palisade parenchyma consisted of one layer of elongated cells and the spongy parenchyma showed 4-5 layers of cells with varying shapes and noticeable intercellular spaces (Figure 1A). 
The bicollateral vascular bundles were immersed in the mesophyll of the four species studied, with intraxylary phloem (Figure 1G), which is a characteristic of the Solanaceae (Metcalfe and Chalk, 1983). Vesque (1875) discovered this type of cambium for the first time in the Solanaceae, Asclepiadaceae and Apocynaceae. Although intraxylary phloem, which is unidirectional and differentiated only into phloem elements in the centripetal direction, is reported in several other families, there are very few species that develop internal cambium at the pith margin.

The petiole of the 4 species studied, when viewed in cross-section and at the level of leaf insertion on the branches, exhibited a concave-convex contour. The epidermis was uniseriate and its cells were covered with a thin cuticle. The cortex was composed of 4-5 subepidermal layers of the angular collenchyma represented by 2-3 cells layers (Figure 1H). The parenchyma cells displayed a isodiametric shape, which varied in size and exhibited intercellular spaces of the meatus type (Figure 1I). The vascular system was arranged in an arc, with the phloem surrounding the xylem on both sides, featuring a bicollateral vascular system in the four species studied. Trichomes with verrucose ornamentation on the surfaces of the petiole were observed in the species C. annuum, C. chinense and C. frutescens (Figure 1J and K).

\section{Seed anatomy}

The seeds of the species studied were similar in structure and shape, but varied in relation to size (Table 3). These seeds were campylotropous, (Figure 2A), ellipsoid, long, and broad oval in longitudinal section (Figure 2B), elliptical in cross-section, with plicata on the longitudinal plane and constituted of embryo, endosperm and a mantle consisting of a silver film.

Table 3. Mean length, width and thickness of seeds from Capsicum species.

\begin{tabular}{lcccc}
\hline Species & Length $(\mathrm{mm})$ & Width $(\mathrm{mm})$ & Thickness $(\mathrm{mm})$ & Weight of 1000 seeds $(\mathrm{g})$ \\
\hline C. chinense & 4.37 & 3.92 & 0.82 & 6.57 \\
C. annum & 2.94 & 3.23 & 0.71 & 5.18 \\
C. baccatum & 2.71 & 2.84 & 0.77 & 5.91 \\
C. frutescens & 2.69 & 3.18 & 0.61 & 4.29 \\
\hline
\end{tabular}

$\mathrm{N}=100$ individuals.
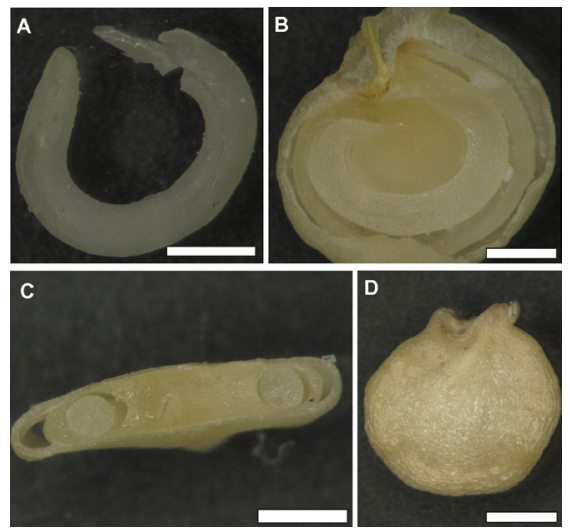

Figure 2. Capsicum sp. A. Longitudinal section of the embryo axis of circinate type. B. Longitudinal section of entire seed showing its ellipsoids, long, broad oval shape. C. Cross-section of entire seed showing its elliptic shape. D. Seeds of the C. chinense. Bars: A, C and D = 1.6X $(1 \mathrm{~mm}) ; \mathrm{B}=1.2 \mathrm{X}(1 \mathrm{~mm})$. 
The seeds of the four species of Capsicum were albuminous (endosperm persists during the development of the embryo), with abundant endosperm, semi-transparent and whitish coloration (Figure 3A). In the literature, there are no reports of seeds with colors darker than the embryos. All four species had a circinate embryo (Figure 3A and B), and in general, the forms described fall within the characteristics described by Barroso et al. (1999) for the family Solanaceae. The tegument was reduced to an inner and outer layer with collapsed mesophyll (Figure 3C). The outer epidermis was uniseriate and juxtaposed, and their cells showed smooth external periclinal walls slightly undulated. The conspicuous thickening of the inner periclinal wall is highlighted in Figure 3, which was lignified as evidenced by the greenish-blue color with toluidine (Figure 3D). The epidermis consisted of an inner layer of cells with long, flat and rectangular shapes (Figure 3E). These characteristics coincide with those observed with scanning electron microscopy (Figure 3C). The tegument epidermis was differentiated in the four species, when observed by scanning electron microscopy. These differences are features that can aid the taxonomic identification of these species, as also stated by Castellani et al. (2008).
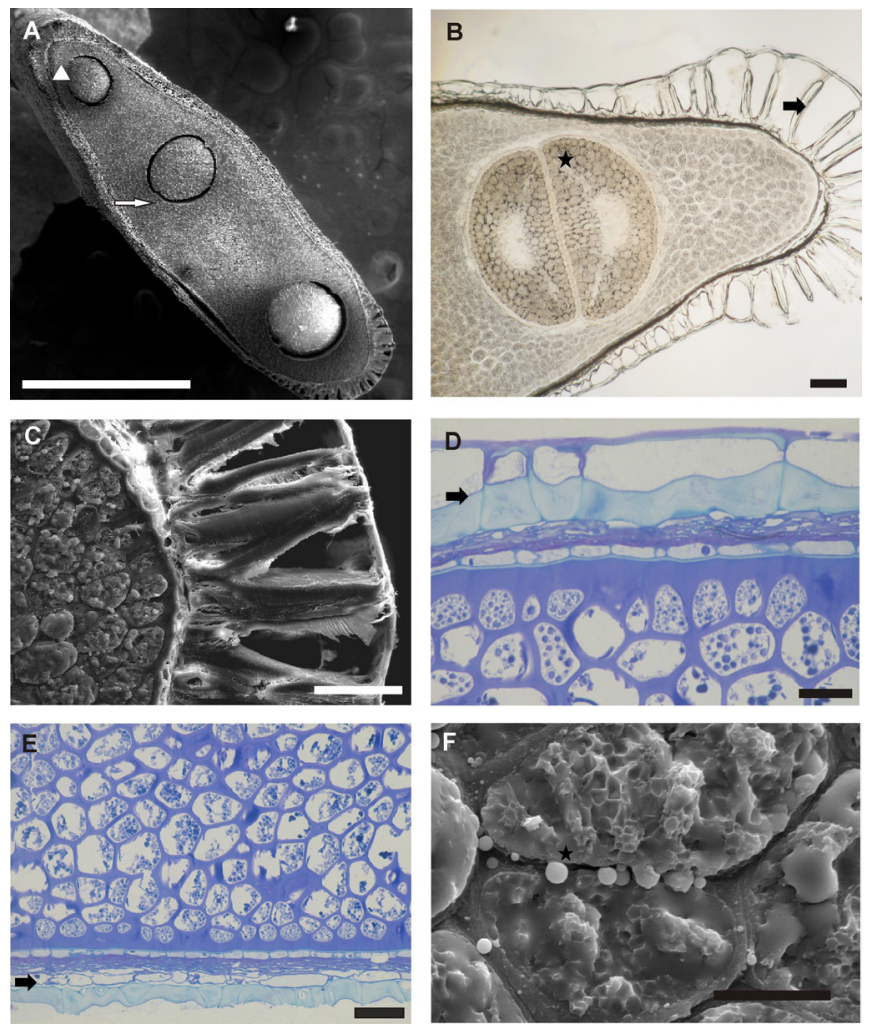

Figure 3. A. Cross-section of seed visualizing the embryonic axis (triangle) and a double cotyledon (arrow). B. Cross-section of seed visualizing the cotyledon (star) and testa (arrow). C. Surface of the outer epidermis of the integument with strongly undulating anticlinal wall. D. Epidermis external layer formed from a compact cell more or less thickened wall cells and undulated (arrow). E. Epidermis, which the internal layer is generally rectangular and with elongated cells (arrow). F. Detail of starch granules in the endosperm (star). Bars: A=1 mm; B $=200 \mu \mathrm{M}$; $\mathrm{C}=50 \mu \mathrm{M} ; \mathrm{D}$ and $\mathrm{E}=20 \mu \mathrm{M} ; \mathrm{F}=10 \mu \mathrm{M}$. 


\section{Fruit anatomy}

According to Knapp (2002), pepper fruits in the conventional sense are classified as berries, that is, simple indehiscent fruit with pericarp that contains many seeds embedded in a solid mass and fleshy, with epicarp less than $2 \mathrm{~mm}$ in thickness and with air space between the seeds and pericarp.

Generally, the fruits of the four species investigated are small to medium, ranging from 1 to $8 \mathrm{~cm}$ in diameter (Costa et al., 2009). The fruits have many variations in color and shape (Moscone et al., 2007). They may be red, for example, C. annuum, C. baccatum and $C$. frutescens, or brown like $C$. chinense. The pericarp is composed of three clearly distinct areas: the exocarp, mesocarp and endocarp.

The exocarp of the fruits of the four studied species had uniseriate and smooth epidermis, with no overlapping tabular cells and with dense-textured and cellulosic walls typically found in berries. The cuticle was highly variable and usually thick as shown in the fruit of $C$. chinense (Figure 4A). In all species, the cuticle layer was present between the epidermal cells. Immediately below the epidermis, a differentiated hypodermis comprising several layers of a collenchyma was observed in C. frutescens (Figure 4B).
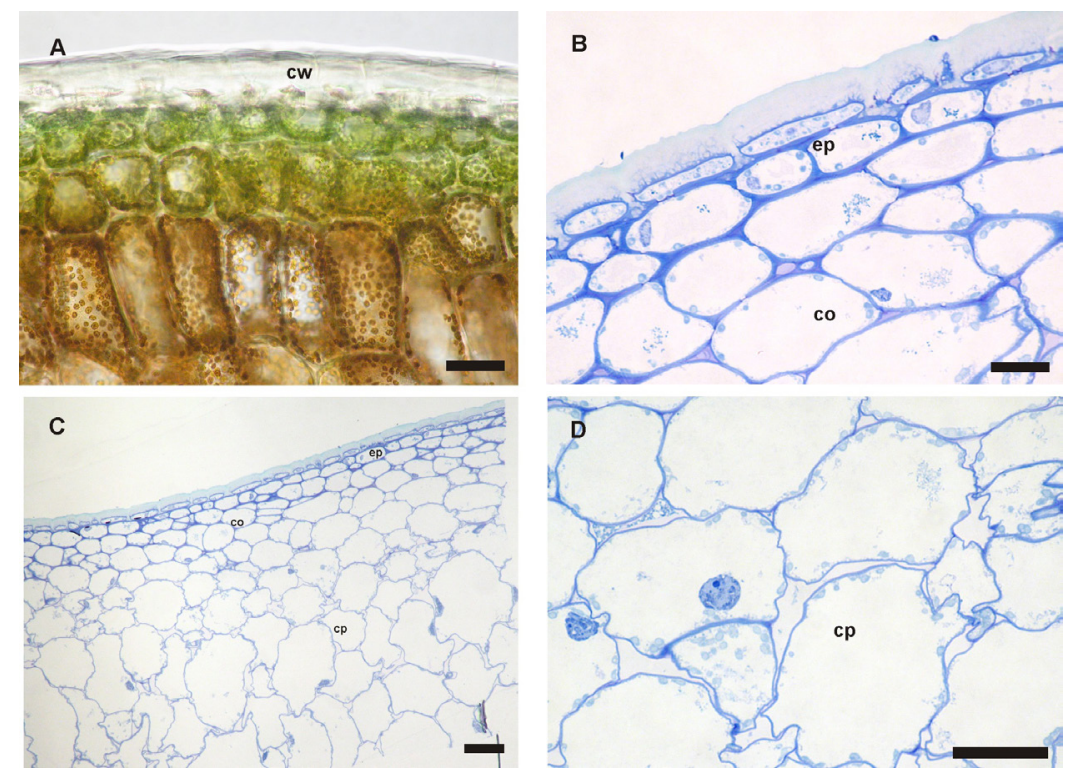

Figure 4. Cross-sections of the fruit of Capsicum sp. A. Detail of the cuticle of the fruit. B. Exocarp. C. Mesocarp. D. Detail of the endocarp. $\mathrm{cw}=$ cell wall; $\mathrm{ep}=$ epidermis; $\mathrm{co}=$ collenchyma; $\mathrm{cp}=$ cortical parenchyma. Bars: $\mathrm{A}$ and $\mathrm{B}=20 \mu \mathrm{M} ; \mathrm{C}=10 \mu \mathrm{M} ; \mathrm{D}=40 \mu \mathrm{M}$.

The epidermis and hypodermis constitute a unit, the exocarp, which generally have layers with gradually decreasing degrees of lignification from the outside to inside of the fruit. Normally, in immature fruits, the cell layers located below the epidermis show chloroplasts and chromoplasts. In ripe fruits, chloroplasts disappear and the cells become compressed. The collenchyma is always present, with the number of layers and degree of lignification varying according to the species (Chiarini and Barboza, 2008). 
The mesocarp comprised two histologically distinct zones: an external (immediately below the hypodermis) and an internal one. The external zone may have two forms, according to the kind of cell arrangement (Chiarinini and Barboza, 2008). The greater the number of mesocarp layers, the greater the thickness of the pericarp was. Fruits with a thick pericarp usually had more than 10 layers. The four species of Capsicum studied showed mesocarp composed of five collenchyma layers, followed by the parenchyma and vascular bundles accompanied by external fibers (Figure 4C).

Finally, no specific particularities were observed in the endocarp. This layer, which is very difficult to observe due to its delicate structure, was uniseriate and lacked stomata in all species studied. It appeared to be composed of parenchyma cells with different sizes and shapes and thin walls (Figure 4D). It is a well-known fact that the collenchyma is followed by a thick-walled parenchyma and that it is also difficult to draw a line between the two tissue types (Chiarini and Barboza, 2008).

\section{Molecular analysis}

A total of 41 primers were tested, and of these, 26 were selected and evaluated in regard to the number of bands generated and also the polymorphism observed with these bands. We obtained a total of 331 bands, of which $323(91.2 \%)$ were polymorphic and 41 monomorphic (8.5\%) (Table 2).

The average number of polymorphic bands produced by the primers was 12.03 . The most polymorphic primer was $(\mathrm{CT})_{8} \mathrm{GC}$ (indicated by number 21, Table 2), generating 27 polymorphic bands, followed by primer $\mathrm{CGA}_{7}$ (indicated by number 16, Table 2), generating 24 polymorphic bands, $(\mathrm{CT})_{8} \mathrm{AC}$ (indicated by number 20 , Table 2 ), generating 20 polymorphic bands, (GT) $)_{6} \mathrm{GG}, \mathrm{TACA}(\mathrm{GCA})_{3} \mathrm{G}$ (indicated by number 19 , Table 2 ), generating 12 polymorphic bands, and (GAA)EAA, $\mathrm{CGA}_{7}, \mathrm{~T}(\mathrm{TTA})_{4} \mathrm{TT}$ and $(\mathrm{GTG})_{4} \mathrm{RC}$ (indicated by numbers 13,14 and 15, Table 2), generating 14 polymorphic bands.

The dendrogram generated based on the molecular data indicated the formation of two main groups (Figure 5), the first one containing accessions of C. annuum, C. baccatum and $C$. frutescens and the second group containing only the accessions of $C$. chinense. In the first group, although it had been separated by species, the accessions formed 2 subgroups, one gathering accessions of $C$. frutescens and the other gathering the species $C$. baccatum and $C$. annuum. The dendrogram generated by the molecular characters also showed a cluster pattern different from the proposed division of the Capsicum genetic complex (Pickersgill, 1991). In this proposal, the genetic complex of $C$. annuum encompasses the domesticated species of C. annuum var. annuum, $C$. chinense and $C$. frutescens, which demonstrates the existence of a great proximity and higher possibility of gene exchange between these species, which also happens in the genetic complex of $C$. baccatum, which includes the $C$. baccatum varieties pendulum, baccatum and praetermissum and also C. tovarii (Tong and Bosland, 1999).

In our study, molecular analyses clustered $C$. baccatum with $C$. annuum and $C$. frutescens, separating the latter two species from $C$. chinense. The same result was observed by Costa et al. (2009) working with RAPD markers and morphoagronomic descriptors to estimate the genetic diversity between Capsicum accessions. In analyzing only morphoagronomic descriptors, these authors found accessions from C. baccatum, C. annuum and C. frutescens in the same cluster, while $C$. chinense accessions were placed in a different cluster. Also, the 
authors hypothesized that this clustering could indicate some closeness and the possibility of gene exchange between $C$. baccatum, $C$. annuum and $C$. frutescens. The results obtained by Monteiro et al. (2011) support this hypothesis, since fertile hybrids were obtained between the species C. annuum var. annuum (sweet or hot pepper) and C. baccatum var. pendulum with pollen viability exceeding $90 \%$. Moreover, Potnis et al. (2012) transferred one gene that controls resistance to bacterial spot from $C$. baccatum to $C$. annuum, showing that gene exchange between different Capsicum species is quite feasible.

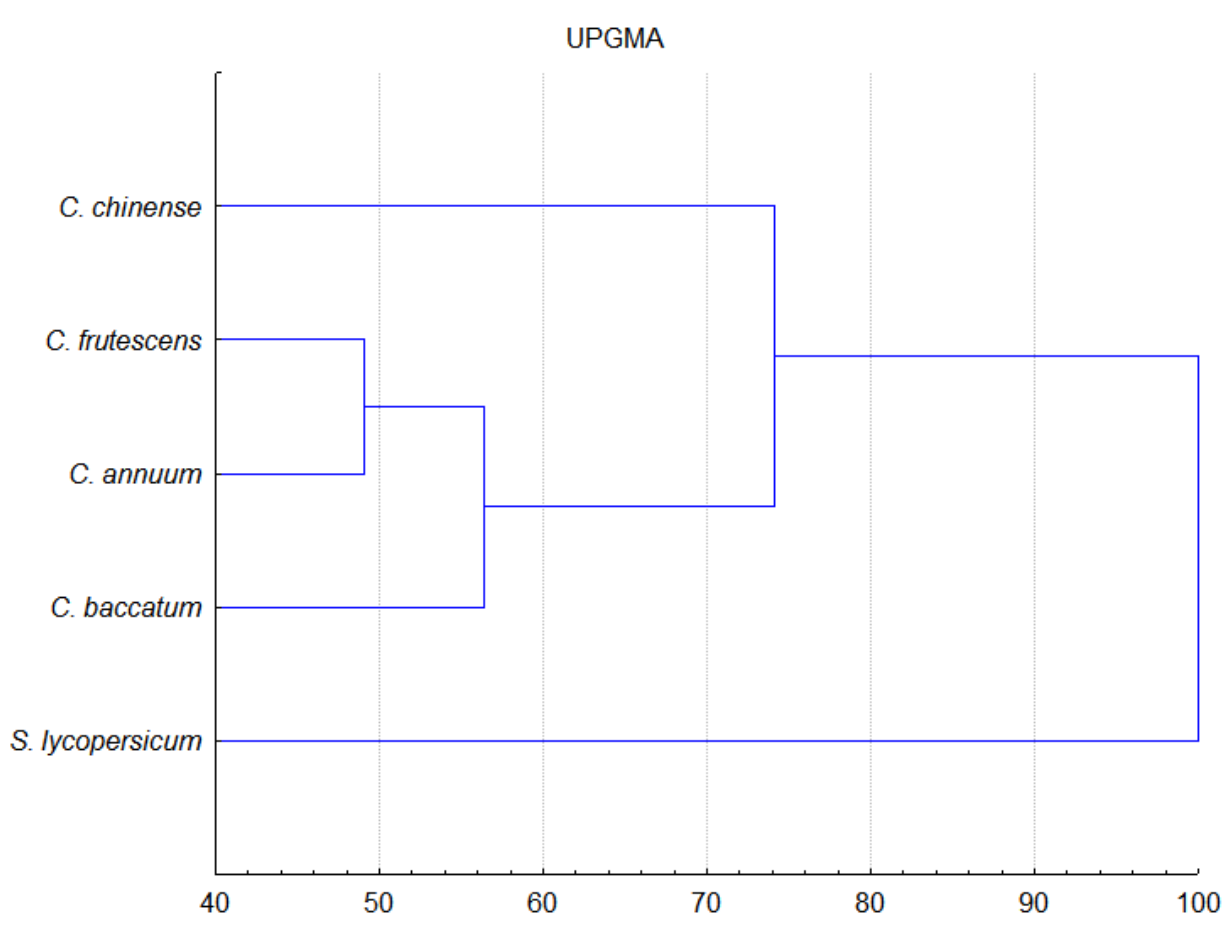

Figure 5. Dendrogram obtained by the UPGMA method based on molecular markers among the 4 accession of Capsicum spp belonging to the germplasm bank collection of Universidade Estadual do Norte Fluminense.

Despite the extensive polymorphism observed for ISSR markers, along with polymorphism for fruit and other agronomic traits, these differences were not reflected in the large variability for anatomical descriptors. Some studies concluded that the association between morphological, agronomic and molecular data is the most suitable approach to estimate Capsicum genetic divergence (Costa et al., 2009) or that joint analysis of quantitative and qualitative data resulted in greater efficiency in the determination of genetic divergence among the Capsicum accessions (Moura et al., 2010). Multivariate strategies such as the Ward-MLM methodology in data analysis for morphoagronomic characterization of accessions have allowed, with some level of efficiency, the separation of Capsicum species with the simultaneous use of morphological and agronomic variables (Sudré et al., 2010). However, Sudré et al. (2010) observed that only morphological descriptors can efficiently discriminate between Capsicum species and their botanical varieties. 


\section{CONCLUSION}

Taking into consideration the complexity of the taxonomic classification of the genus Capsicum (Barbosa et al., 2006), the comparative study of the anatomy of four species of Capsicum demonstrated the existence of some anatomical variations between $C$. baccatum, C. annuum, $C$. chinense, and C. frutescens. However, many characters were present in the four species and may be typical of the genus. Polymorphism in the morphology and type of trichomes of C. baccatum, C. annuum, C. chinense, and C. frutescens can result in differential characters of these species. Some of these characters are valid in distinguishing the species of Capsicum and can also contribute to the taxonomic studies of Solanaceae plants. Other descriptors should be taken into consideration, such as flower morphology, to help in describing and discriminating Capsicum accessions. As expected, ISSR markers were able to detect a high level of polymorphism, but it was not reflected in anatomical ultrastructural characters.

\section{ACKNOWLEDGMENTS}

Research supported by the Brazilian agencies CNPq, FAPERJ and CAPES. We are grateful to G.A. Moraes, B.F. Ribeiro, M.A.S.C. Dutra, and L.C.D. Souza for general laboratory technical support. This study is part of a doctoral thesis presented by G.B. Dias carried out at Universidade Estadual do Norte Fluminense.

\section{REFERENCES}

Amme S, Rutten T, Melzer M, Sonsmann G, et al. (2005). A proteome approach defines protective functions of tobacco leaf trichomes. Proteomics 5: 2508-2518.

Barbosa RI, Luz FJF, Nascimento Filho HR and Maduro CB (2006). Pimentas do gênero Capsicum cultivadas em Roraima, Amazônia Brasileira. I. Espécies domesticadas. Acta Amazonica 32: 177-192.

Barroso GM, Morim MP, Peixoto AL and Ichaso CLF (1999). Frutos e Sementes: Morfologia Aplicada à Sistemática de Dicotiledôneas. Viçosa Imprensa Universitária, Universidade Federal de Viçosa, Viçosa.

Carlquist S (1958). Structure and ontogeny of glandular trichomes of Madinae (Compositae). Am. J. Bot. 45: 675-682.

Castellani ED, Damião Filho CF, Aguiar IB and Paula RC (2008). Morfologia de frutos e sementes de espécies arbóreas do gênero Solanum L. Rev. Bras. Sementes 30: 102-113.

Chiarini FE and Barboza GE (2008). Karyological studies in Jaborosa (Solanaceae). Bot. J. Linn. Soc. 156: 467-478.

Clement CR, Cristo-Araújo M, d'Eeckenbrugge GC, Pereira AA, et al. (2010). Origin and domestication of Native Amazonian crops. Diversity 2: 72-106.

Cosa MT, Hadid M, Dottori N and Bruno G (2002). Anatomía de órganos vegetativos en Solanum palinacanthum, $S$. sisymbriifolium y S. euacanthum (Solanaceae). An. Inst. Biol. Univ. 73: 27-38.

Costa FR, Pereira TNS, Sudré CP and Rodrigues R (2009). Marcadores RAPD e caracteres morfoagronômicos na determinação da diversidade genética entre acessos de pimentas e pimentões. Cienc. Rural 39: 696-704.

Cruz CD (2006). Programa GENES: Estatística Experimental e Matrizes. Universidade Federal de Viçosa, Viçosa.

Doyle JJ and Doyle JL (1990). Isolation of plant DNA from fresh tissue. Focus 12: 13-15.

FAOSTAT (2010). Agricultural Production Data. Available at [http://faostat.fao.org/]. Accessed May 14, 2012.

Granada-Chacón WA and De Rojas BCE (2004). Anatomia foliar de cuarto especies de Solanum L. sección Acanthophora Dunal en Venezuela. Acta Cient. Venez. 55: 13-26.

IBPGR (1983). Genetic Resources of Capsicum. IBPGR Secretariat, Rome, 13.

Ince AG, Karaca M and Onus AN (2009). Development and utilization of diagnostic DAMD-PCR markers for Capsicum accessions. Genet. Resour. Crop Evol. 56: 211-221.

Klein DE, Gomes VM, Neto SJS and Da Cunha M (2004). The structure of colleters in several species of Simira (Rubiaceae). Ann. Bot. 94: 733-740.

Knapp S (2002). Tobacco to tomatoes: A phylogenetic perspective on fruit diversity in the Solanaceae. J. Exp. Bot. 53: 2001-2022. 
Kumar R, Dwivedi N, Singh RK, Kumar S, et al. (2011). A review on molecular characterization of pepper for Capsaicin and Oleoresin. Intl. J. Plant Breed. 5: 99-110.

Laurentin H (2009). Data analysis for molecular characterization of plant genetic resources. Genet. Res. Crop Evol. 56: 277-292.

Maiti RK, Villarreal LR, Trevino AV and Valades-Cerda MC (2002). Some aspects on pharmacology of ten species of the family Solanaceae utilized in traditional medicine. Caldasia 24: 317-321.

Metcalfe CR and Chalk L (1950). Anatomy of the Dicotyledons: Leaves, Stem, and Wood in Relation to Taxonomy with Note on Economic Uses. University Press, Oxford.

Metcalfe CR and Chalk L (1983). Anatomy of the dicotyledons 2, 2. Nord. J. Bot. 4: 668.

Mongkolporn O and Taylor PWJ (2011). Capsicum. Wild Crop Relatives: Genomic and Breeding Resources, 43-57.

Monteiro CES, Pereira TNS and Campos KP (2011). Reproductive characterization of interspecific hybrids among Capsicum species. Crop Breed. Appl. Biotechnol. 11: 241-249.

Moraes TMS, Rabelo GR, Alexandrino C, Neto SJS, et al. (2011). Comparative leaf anatomy and micromorphology of Psychotria species (Rubiaceae) from the Atlantic Rainforest. Acta Bot. Bras. 25: 178-190.

Moscone EA, Scaldaferro MA, Grabiele M, Cecchini NM, et al. (2007). The evolution of chili peppers (Capsicum Solanaceae): a cytogenetic perspective. Acta Hortic. 745: 137-169.

Moura MCCL, Gonçcalves LSA, Sudré CP, Rodrigues R, et al. (2010). Algoritmo de Gower na estimativa da divergência genética em germoplasma de pimenta. Hort. Bras. 28: 155-161.

O’Brien TP, Feder N and McCully ME (1964). Polychromatic staining of plant cell walls by toluidine blue O. Protoplasma 59: 368-373

Patel AS, Sasidharan N, Ashish GV and Kumar V (2011). Genetic relation in Capcicum annum [L.] cultivars through microsatellite markers: SSR and ISSR. Intl. J. Plant Breed. 2: 67-76.

Perry L, Dickau R, Zarrillo S, Holst I, et al. (2007). Starch fossils and the domestication and dispersal of chili peppers (Capsicum spp. L.) in the Americas. Science 315: 986-988.

Petters PJ (2002). Correlations between leaf structural traits and the densities of herbivorous insect guilds. Biol. J. Linn. Soc. Lond. 77: 43-65.

Pickersgill B (1991). Cytogenetics and Evolution of Capsicum L. In: Chromosome Engineering in Plants: Genetics, Breeding Evolution (Tsuchia T and Gupta PK, eds.). Elsevier Science Publishers, Amsterdam, 139-160.

Potnis N, Minsavage G, Smith JK, Hurlbert JC, et al. (2012). Avirulence proteins AvrBs7 from Xanthomonas gardneri and AvrBs1.1 from Xanthomonas euvesicatoria contribute to a novel gene-for-gene interaction in pepper. Mol. Plant Microbe Interact. 25: 307-320.

Price PW (1997). Insect Ecology. John Wiley \& Sons, New York, 874.

R Development Core Team (2009). R: A Language and Environment for Statistical Computing. R Foundation for Statistical Computing, Vienna.

Refaat MH and Hoda AS Elgarhy (2007). Relationship between hybrid performance and genetic diversity based on ISSRPCR markers in Pepper (Capsicum annuum L.). Ann. Agric. Sci. 45: 1565-1579.

Reifschneider FJB and Ribeiro CSC (2008). Cultivo. In: Pimentas Capsicum (Ribeiro CSC, Lopes CA, Carvalho SIC, Henz GM, et al., eds.). Embrapa Hortaliças, Brasilia, 11-14.

Simmons AT, Gurr GM, McGrath D, Nicol HI, et al. (2003). Trichomes of Lycopersicon spp. and their effect on Myzus persicae (Sulzer), Hemiptera: Aphidae. Austr. J. Entomol. 42: 373-378.

Smith WK, Volgemann TC, Delucia EH, Bell DT, et al. (1997). Leaf form and photosynthesis. BioScience 47: 785-793.

Sudré CP, Goncalves LS, Rodrigues R, do Amaral Junior AT, et al. (2010). Genetic variability in domesticated Capsicum spp as assessed by morphological and agronomic data in mixed statistical analysis. Genet. Mol. Res. 9: 283-294.

Tong N and Bosland PW (1999). Capsicum tovarii, a new member of the Capsicum baccatum complex. Euphytica 109: 71-77.

Vesque J (1875). Mémoire sur l'anatomie comparée de l'écorce. Ann. Sci. Nat. Bot. 2: 82-198.

Vilela NJ, Ribeiro CSC and Madail JCM (2008). Eficiência Técnico-Econômico de Quatro Sistemas de Produção de Pimentas Capsicum. Embrapa Hortaliças, Brasília, 7.

Williams JG, Kubelik AR, Livak KJ, Rafalski JA, et al. (1990). DNA polymorphisms amplified by arbitrary primers are useful as genetic markers. Nucleic Acids Res. 18: 6531-6535. 